\title{
THE INDIAN SCENE
}

\section{PROFIT AND LOSS ACCOUNT}

(From information given in The Statesman, by Mr. E. P. Gec)

On the credit side can be put increases in the Indian lion and the great Indian rhinoceros.

In 1950 the lion population of the Gir Forest was carefully assessed at 250 (sec Oryx, vol. I, No. 2, pp. 99-101). In 1955 a similar census gave 290 , an increase of 40 in four years, though the proportion of cubs to adults had decreased.

It is not possible to count the rhinoceroses for they live in inaccessible swampy country, often in elephant grass up to 15 fect high, but Mr. Gee's estimate of 440, which includes 250 in Kaziranga, is based on his great experience of this rhinoccros.

On the credit side must also be put the untiring efforts of the Indian Board for Wild Life to formulate a preservation policy for India, with detailed recommendations to all the States on the innumerable facets of wild life preservation. These include legislation, close seasons, illicit shooting, crop protection, trade, education and publicity. State wild life boards have been formed and are tackling these problems with varying degrees of effectiveness. Many improvements have been made in wild life sanctuaries. The foundations have been soundly laid; it remains for the edifice to be built.

On the debit side there is the loss of the chectah and the pink-headed duck and probably of the Manipur brow-antlered deer. Tigers are becoming rarer, as are clephants, blackbuck, the great Indian bustard, the white-winged wood duck and the great Indian hornbill.

"But," writes Mr. Gec, "the main item on the debit side is the indiscriminate killing of wild life, chicfly decr, which continues unabated. Many persons, sometimes even Government officials, we are told, still go out in jecps, cars and trucks by night in order to shoot anything they can see in the headlights or spotlight of the vehicle. Nothing is spared; females, immature males and young-all are butchered. Other people annililate masses of fish by dynamiting and bombing our rivers, mainly in the hilly areas-another form of stupid destruction of a valuable asset. $A$ strong and enlightened public opinion is urgently needed so that the poacher and law-breaker may become discredited and brought to book." 


\section{THE TIGER}

Letters have appeared in the English press expressing fears for the survival of the tiger. Comments in The Statesman on these letters by Mr. M. D. Chaturvedi, formerly DirectorGeneral of Forests, India, give ground for hoping that the immediate extinction of the tiger need not be feared.

The number of tigers shot yearly since the last war has not decreased very much : heads of forest departments report an increase of tigers in Bengal, stationary population in Madras and Mysore, decline in Madhya Pradesh and Uttar Pradesh. Luckily the tiger breeds freely in the wild. Litters may be as high as six, but normally only two are found at heel. A tigress starts breeding at about four years old and has a litter at least every third or fourth year ; she may be depended upon to raise three cubs during an average life span of ten years.

WEAPONS OF THE GREAT INDIAN RHINOCEROS

\section{A Communication from MIr. E. O. Simebreare}

Mr. E. P. Gee, in a letter, describes an attack on an elephant by a great Indian rhinoceros in defence of her calf. The elephant attacked was one from which Mr. L. MI. 'Talbot, ecologist of the International Union for the Protection of Nature, was watching the rhinos, and it received a gash $1 \frac{1}{2}$ inches long by 2 inches decp. The wound was made by one tush only and the horn not used.

Though I have never witnessed such an attack, I have always mysclf thought that-apart from trampling on its victim, which may be accidental-the Indian rhino's only offensive weapons were these "tushes", perhaps better deseribed as the outer pair of lower incisors, since rhinos have no canines. Unlike the middle pair of incisors, these are pointed and usually very sharp (sce Blanford, Fauna of British India, Mammals, p. 471). I remember how Bena, a Bengali tracker, who had once been hoisted by a rhino on to the crupper-ropes of a retreating padelephant, used to demonstrate, with his own. lower incisors, how the lift had been effected, and the healed scars on his loins fully bore him out. The horns of the Asiatic rhinos are often not much sharper than the pointed toc of a shoe and, being only consolidated hair, not so very much harder.

It would be interesting to be assured, by those who know the far fiercer and more efficiently horned African rhinos, that these do actually use their horns as weapons-as one would naturally suppose they do. 
If not as weapons, what do Asiatic rhinos use their horns for? I have been told that they are for grubbing roots and knocking over ant-hills. One certainly often sces areas, several square yards in extent, grubbed up, especially in old, burnt savannah, and mahouts have assured me that this was the work of rhinos. Unfortunately the work of pigs looks identical to me at any rate, so that until I have seen a rhino thus using its horn I should prefer to be guarded in my statement. Similarly one often sees ant-hills levelled, but again, I have not seen a rhino using his horn for this ; sloth bears certainly flatten out ant-hills in their search for their daily bread, termites.

\section{MANAGEMENT OF FOREST LANDS FOR WILD LIFE}

(From a paper presented to the Fourth World Forestry Congress in Dehra Dun, December, 1954, by K. S. Dharmakumarsinhiji, Vice-Chairman, India Board for Wild Life.)

It is accepted as a general principle that the importance of good timber supersedes the interest of wild life in forest land. But this does not necessarily mean that wild life should be neglected and has no place in forest planning. Wild Life is a part of forest produce and its existence depends upon forest vegetation.

The problem is to discover which species are most advantagcous to the growth of the forests, so that we can encourage the species which are least harmful or are conducive to the regeneration and growth of forest trees.

Because a small animal like a red squirrel stores its food of nuts and seeds in holes and forgets it, forest trees germinate and develop. In the deciduous forests and grasslands of India, the nilgai feeds upon the leguminous seed pods of hardwoods and defacentes the seeds for better regeneration. In the Rajasthan district of India, where afforestation with Prosopis juliflora is being undertaken, it might be possible to assist the cxpansion of the forest by introducing nilgai. According to my experience, the nilgai feeds upon the fruits of Balanites roxburghii and disperses the seeds, which germinate rapidly. Indian birds such as mynas, barbets and fruit pigeons feed cxtensively upon fruits, especially of Ficus and Necm trecs. 'The seeds are scattered in their excreta and germinate rapidly. 'To what extent can we take advantage of these beneficient creatures?

The over-abundance of game in forest land becomes a problem where regeneration of trees is concerned. Browsing of sal trees 
by sambar and chital may be so intense as to prevent regeneration. Destruction of plants by porcupines is also very great. Is fencing the answer or the reduction of the harmful animals ? Success might be achieved by an increase of forest trees with palatable fruit, on which the animals could feed. An adequate number of predatory animals would help, but their increase would have to be reaped when it exceeded the forest's capacity.

The complex relationship between flesh-eating animals and their prey has long been misunderstood and many crimes against the carnivorous animals have been committed in the name of conservation. Predators check the increase of both beneficial and harmful animal species and to control predators by reducing them to the eategory of vermin is now considered of doubtful value. To reason that if one removes a predator the population of its prey will increase is also often fallacious. The biological conditions are so variable that a species may become a pest in one place and a friend in another.

The red dogs, Cuon, in central and southern India are a scourge to wild life and their use as controllers of over-abundance of game is long past. Should the species therefore be killed off ruthlessly? IIere the word vermin might be used in its full sense, where the animal.serves no useful purpose anywhere.

Predators such as the lion, tiger and leopard are very useful in forest land in India. According to my experience, the presence of a predator not only checks over-population and disposes of diseased and wounded animals, but it improves the virility of the prey. Wild boars living alongside the lions in the Gir Forest are much better specimens and displny much more courage than those living outside.

It has been proved in practice that forest work is beneficial to wild life. "Fortunately proper forest management is also good decr management and a programme of frequent cuttings, systematically applied, is the best guarantee of a satisfactory and reasonably stable habitat" ('Tripensec). There is therefore no renson why forest work cannot be undertaken on a small scale even in national parks. If a national park is primarily a wild life park, the improvement of conditions for wild life is $\Omega$ further reason why the forest would be worked. "As even-aged stands advance from the seedling stage into middle age, the volume of available browse becomes progressively less abundant; at times decreasing even to the point of scarcity in stands of abnormal density. Cutting is the only remedy for a situation of this kind" ('Iripensec).

This brings us to the best method of cutting forest land. 
The ideal forest for wild life is where vegetation is seen in all its stages, with a mixed varicty of trees, especially fruit trees. Clear cutting increases grass cover which is of great use to wild life provided the hot weather shelter trees are preserved.

"The strip and the group shelterwood methods are more desirable for wild life than the uniform shelterwood method because of the variety of the age classes created and the regularity with which cutting operations are spread, in point of time, through the stand" (Tripansec). The cutting of large trees during the breeding scason of birds dwelling in hollows, may have ill consequences; it was partly the cause of the extinction of the grey hornbill in the Gir Forest. The good management of wild life should improve natural regencration of forest trees and the control of harmful insects by the increase of birds. The inerease of the game crop adds also to the forest income.

If a large unit is being worked on a sustained yield basis under a cutting cycle, it is better from the wild life standpoint to cut cach year a number of well distributed small blocks than to make the whole annual cut in one piece.

The administration of wild life in forest land can only be suecessful when the wild life officer has made some study of forestry and vice versa. It fails when there is no direct control or where legislation leaves a gap for the escape of poachers, or punishment is negligible. There is a limit to the work a man can do efficiently. In India, 6 to 12 sq. miles for each forest guard is laid down as a general principle.

'The absolute prevention of fire in forest land is well nigh impossible. Control burning in winter, when there is lenst damnge to wild life and trees alike, may reduce losses during the hot season, but certain useful birds breed during the winter and regular control burning may effect their populations scriously. Methods should be devised to keep patches of the grass cover immune from burning during the short brecding scason of important species.

The manngement of wild life depends upon the study of the habits of individual wild animals. When these are put together and added to the pattern of vegetation and the soil formula, the complete picture is made up.

Nole.-Mr. R. S. Dharmakumnrsinhji, T.Z.S., M.B.O.U., is the nuthor of Birds of Saurausthra-India, recently published and obtainable from N. II. 'Tripatli, I.tel., Princess Strect, I3ombay 2. Price 25 12s. Bd. 


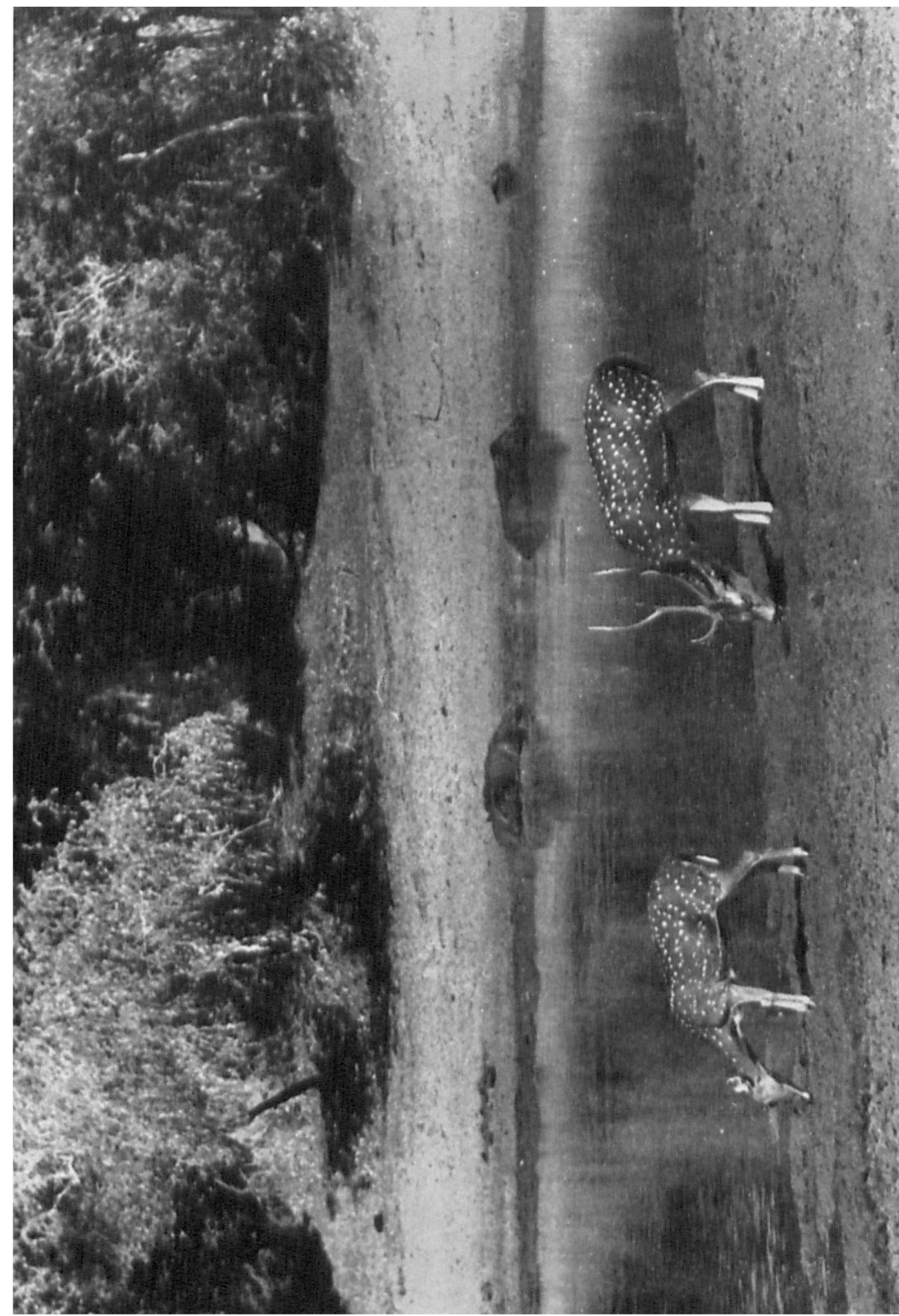

5
$\vdots$
$\vdots$
$\vdots$
$\vdots$

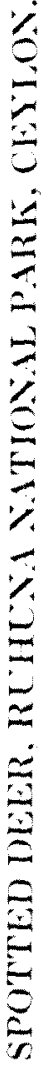

